\title{
Retranslocation of foliar nutrients of deciduous tree seedlings in different soil condition under free-air $\mathrm{O}_{3}$ enrichment
}

\author{
Cong Shi ${ }^{(1)}$, Norikazu Eguchi ${ }^{(1-2)}$, \\ Fankang Meng ${ }^{(1-3)}$, Toshihiro \\ Watanabe ${ }^{(1)}$, Fuyuki Satoh ${ }^{(4)}$, \\ Takayoshi Koike ${ }^{(1)}$
}

\begin{abstract}
Retranslocation is the amount of an element that is depleted from old plant components and is provided for new growth. Leaf senescence is usually accelerated at elevated $\mathrm{O}_{3}\left(\mathrm{eO}_{3}\right)$, and leaf shedding is influenced by soil nutrient availability (and acidification). In this study, we focused on the net retranslocation and allocation dynamics of foliar nutrients $(\mathrm{N}, \mathrm{P}, \mathrm{Mg}, \mathrm{K}, \mathrm{Ca}, \mathrm{Mn}, \mathrm{Fe}$ and Al) to investigate the effect of $\mathrm{eO}_{3}$ on birch (Betula platyphylla var. japonica), oak (Quercus mongolica var. crispula), and beech (Fagus crenata) seedlings grown in different soil conditions. Seedlings of the 3 species were planted in a free-air $\mathrm{O}_{3}$ enrichment system under 3 soil types (brown forest soil, serpentine soil, volcanic ash soil) for one growing season. All tree species were grown with 3 replications per each plot at elevated $\mathrm{O}_{3}$ (about $80 \mathrm{ppb}$ ) and ambient condition $\left(\mathrm{O}_{3}\right.$ ranging $\left.25-35 \mathrm{ppb}\right)$. Leaf samples were taken from the top part of seedlings during the growing season in mid-September, and senescing leaves were sampled in mid-November. Both were collected for chemical composition analysis. Retranslocation rate of $\mathrm{P}$ was markedly increased by $\mathrm{eO}_{3}$ in birch and significantly differed among soil types in oak seedlings, while was constant across treatments in beech seedlings. Retranslocation of $\mathrm{N}$ in oak seedlings was significantly affected by soil type. Retranslocation of other elements was most sensitive to both $\mathrm{eO}_{3}$ and soil type in beech seedlings. The influence of differential growth patterns among species in modulating the physiological response of seedlings to high levels of ozone and different soil conditions are discussed.
\end{abstract}

Keywords: Retranslocation, Foliar Nutrients, Ozone, Volcanic Ash Soil, Serpentine Soil

parameter of nutrient resorption efficiency (NURE), which is defined as the percentage of the foliar nutrient pool absorbed (Huang et al. 2007, Farahat \& Linderholm 2015). Positive NURE values indicate that plants are able to reuse rather than lose their internal nutrients with senescence, therefore plant growth, reproduction and competitive ability will be facilitated and vice versa for negative NURE values (Farahat \& Linderholm 2015).
(1) Graduate School of Agriculture, Hokkaido University, Sapporo 060-8689 (Japan); (2) Present address: Aichi Prefectural Forestry Research Institute, Aichi 441-1622 (Japan); (3) College of Life Science, Nankai University, Tianjin 300071 (China); (4) Hokkaido University Forests, FSC, Sapporo 060-0809 (Japan)

@ Takayoshi Koike (tkoike@for.agr.hokudai.ac.jp)

Received: Sep 30, 2015 - Accepted: Mar 26, 2016

Citation: Shi C, Eguchi N, Meng F, Watanabe T, Satoh F, Koike T (2016). Retranslocation of foliar nutrients of deciduous tree seedlings in different soil condition under free-air $\mathrm{O}_{3}$ enrichment. iForest 9: 835-841. - doi: 10.3832/ifor1889-009 [online 2016-06-17]

Communicated by: Silvano Fares
Retranslocation has been characterized as an important strategy for trees to conserve nutrients, which eventually affects nutrient competition, absorption and productivity (Salehi et al. 2013). It is an essential mechanism for improving plant growth as well as nutrient competitiveness and species conservation (Salifu \& Timmer 2001, Uddling et al. 2006).

These processes of nutrient retranslocation in plants are likely to be affected by plant genetic make-up or plant species, soil fertility, as well as other environmental conditions (Hagen-Thorn et al. 2004). Despite the fact that research has been conducted on the retranslocation response of foliar nutrients, most studies has mainly targeted one or various species (Helmisaari 1992, Salehi et al. 2013) under different soil statuses, for instance, water irrigation and nitrogen fertilization (Salifu \& Timmer 2001, Zhao et al. 2013). Therefore, little information is available for understanding the effects of elevated ozone (hereafter: $\mathrm{eO}_{3}$ ) and its relations and interactions with soil fertility (or acidification) on the retranslocation process of foliar nutrients (Uddling et al. 2006). 
Recently, ground level $\mathrm{O}_{3}$ concentration has been continuously increasing in northeast Asia and is negatively affecting the forest health (Serengil et al. 2011, Koike et al. 2013). Furthermore, elevation of $\mathrm{O}_{3}$ is expected to continuously increase for at least several decades in the foreseeable future (Ohara et al. 2007). In addition, $\mathrm{eO}_{3}$ can accelerate foliar senescence (Hoshika et al. 2012) and reduce the retranslocation rate of nitrogen ( $\mathrm{N}$ - Kam et al. 2015), resulting in nutrient deficiencies in leaves caused by the decline of $\mathrm{N}$ acquisition (Karnosky et al. 2007).

Brown forest soil (mostly Cambisols, $\mathrm{pH}$ 5.4) which is a common soil type for deciduous broad-leaved forests, contains the necessary elements for plant growth (Kayama et al. 2011, Kim et al. 2011). Serpentine soil ( $\mathrm{pH} 7.4)$ is derived from weathered serpentine rock (Brady et al. 2005, Kayama \& Koike 2015) and is characterized by excessive $\mathrm{Mg}$ and heavy metals but a low contents of $\mathrm{Ca}$ and several essential nutrients (Brady et al. 2005). It has a high $\mathrm{pH}$ value and is also known to be widely distributed throughout Japan (Kayama \& Koike 2015). Volcanic ash soil ( $\mathrm{pH} 3.6)$ is an acidic soil that contains high levels of aluminum (Al) and iron (Fe), but low contents in magnesium (Mg), calcium (Ca), manganese ( $\mathrm{Mn}$ ), nitrogen $(\mathrm{N})$ and potassium ( $\mathrm{K}$ - Kayama et al. 2011, Watanabe et al. 2010). As the response of retranslocation seems to be influenced by soil fertility ( $\mathrm{Xu} \&$ Timmer 1999) as well as soil acidification (Gjengedal 1996, Adams et al. 2006), we have planted seedlings on brown forest soil, volcanic ash soil and serpentine soil. These soil conditions represent rich fertility with neutral soil, medium fertility with acidic soil and poor fertility with alkaline soil, respectively.

As the representative of deciduous species in the northern forests of Japan, Japanese white birch (henceforth birch: Betula platyphylla var. japonica), Mizunara oak (oak: Quercus mongolica var. crispula), and Siebold's beech (beech: Fagus crenata) were chosen, since they all provide social, economic and environmental benefits that are important to the cool temperate forests of Japan (Koike 1995, Koike et al. 1998). According to Yamaguchi et al. (2011), $\mathrm{O}_{3}$ tolerance capacity of these 3 species can be ranked from low to high as follows: birch < beech < oak. In general, most early successional tree species retranslocate less nutrients from their leaves before shedding, compared to late successional trees, especially in plants grown in infertile soil condition (Killingbeck 2004, Koike 2004).

In this study, we focus on the retranslocation and allocation dynamics of foliar nutrients ( $\mathrm{N}, \mathrm{P}, \mathrm{Mg}, \mathrm{K}, \mathrm{Ca}, \mathrm{Mn}, \mathrm{Fe}$ and $\mathrm{Al}$ ) to achieve the following major objectives: (i) to determine how $\mathrm{O}_{3}$ concentration affects foliar nutrients retranslocation in birch, beech and oak; (ii) to quantify foliar nutrient retranslocation of element $\mathrm{N}, \mathrm{P}, \mathrm{Mg}, \mathrm{K}$, $\mathrm{Ca}, \mathrm{Mn}, \mathrm{Fe}$ and $\mathrm{Al}$, as well as to examine foliar nutrients retranslocation in different soil sites; (iii) to evaluate the combined effects of both $\mathrm{O}_{3}$ and soil on foliar nutrients retranslocation in birch, beech and oak. Based on the achieved results, we also discuss the plausible understanding of the ecophysiological meaning of retranslocation of each element in leaves in relation to specific traits of $\mathrm{O}_{3}$ effect.

\section{Materials and methods}

\section{Plant materials}

Two-year old seedlings of Japanese white birch (birch: Betula platyphylla var. japonica), Siebold's beech (beech: Fagus crenata) and Mizunara oak (oak: Quercus mongolica var. crispula) were obtained near Sapporo (Hokkaido, Japan), and were planted in mid-July 2014 at the nursery of Hokkaido University, Sapporo. These 3 deciduous tree species are the major components of cool temperate forests in Japan (Koike 1995, Koike et al. 1998). All the seedlings were grown in the same soil-environment and growth media.

\section{Experimental site description}

The experimental site was located in Experimental Nursery of Hokkaido University Forests in the central part of Sapporo, northern Japan ( $43^{\circ} 04^{\prime} \mathrm{N}, 141^{\circ} 20^{\prime} \mathrm{E}, 15 \mathrm{~m}$ a.s.l.) with about a population of 2 million people. Annual mean temperature and the total precipitation in 2014 were $8.2{ }^{\circ} \mathrm{C}$ and $1129 \mathrm{~mm}$ respectively. A free-air $\mathrm{O}_{3}$ enrichment system was utilized at the university experimental nursery with each system having 3 soil types (brown forest soil, serpentine soil, volcanic ash soil) and with each soil type being about $30 \mathrm{~cm}$ in depth. The enrichment lasted for one growing season. The experimental site consists of 3 control and 3 treatment circular plots 6.5 $\mathrm{m}$ in diameter, and with each system being surrounded by $5 \mathrm{~m}$ high dispersal pipes (Kim et al. 2011). Details of the $\mathrm{O}_{3}$ exposure in field station as well as the plot design can be found in Watanabe et al. (2013). $\mathrm{O}_{3}$ concentration of $80 \pm 7 \mathrm{nmol} \mathrm{mol}^{-1}$ was applied during daylight hours (about $7 \mathrm{~h}$ per day) from early-August to mid-November in treatment plots, while at the same time, the control plots were subjected to ambient daytime $\mathrm{O}_{3}$ concentration of 26.5 nmol mol ${ }^{-1}$ (Kam et al. 2015)

Each of the free-air enrichment plot was unevenly divided into 3 parts, replaced with 3 different soil types: about $84 \%$ of the plot area was divided into 2 parts, each equally consisting of brown forest soil (B) and volcanic ash soil (V); about $16 \%$ of the area was serpentine soil (S). All of these soil types are widely distributed across northern Japan (Kim et al. 2011). Brown forest soil is native to the Sapporo Experimental nursery, immature volcanic ash soil was brought from the Tomakomai Experimental Forest of Hokkaido University (Kim et al. 2011) and serpentine soil was brought from the eastern part of Teshio Experimental
Forest (Watanabe et al. 2012), where serpentine soil is dominant (Kayama \& Koike 2015).

When taken together, the system was set up with 6 factorial combination treatments of $\mathrm{O}_{3}$ exposure and soil types in the experimental nursery as follow: ambient $\mathrm{O}_{3} \times \mathrm{B}$ $(\mathrm{AB}), \mathrm{eO}_{3} \times \mathrm{B}(\mathrm{EB})$, ambient $\mathrm{O}_{3} \times \mathrm{S}(\mathrm{AS}), \mathrm{eO}_{3}$ $\times \mathrm{S}(\mathrm{ES})$, ambient $\mathrm{O}_{3} \times \mathrm{V}(\mathrm{AV}), \mathrm{eO}_{3} \times \mathrm{V}(\mathrm{EV})$

\section{Collection of samples and measurements}

Samples of live and senescing leaves were taken from 3 seedlings per species in each treatment (4 trees per replication) in two-stages: for live leaves, samples were taken in mid-September during the peak nutritional activities of seedlings, while for senescing leaves samples were taken in mid-November (Shi et al. 2016). The top crown or second leaf counted from the shoot-top was collected as live leaves. After rinsing their surface with distilled water, both collected live and senescing leaves were dried at $70{ }^{\circ} \mathrm{C}$ for at least 5 days. Afterward, all the leaves were mill ground into powder to be used for further analysis.

In order to analyze the projected elements ( $\mathrm{N}, \mathrm{P}, \mathrm{Mg}, \mathrm{K}, \mathrm{Ca}, \mathrm{Mn}, \mathrm{Fe}$ and $\mathrm{Al}$ ), the powdered leaf samples were digested by nitric acid, hydrogen peroxide method and the concentration was measured with an Inductively Coupled Plasma Mass Spectrometry (ICP-MS, IRIS/IRIS Advantage ICAP, Thermo Fisher Scientific Inc., MA, USA) analysis. $\mathrm{N}$ concentration was determined by the combustion method using a NC analyzer (NC-90o, Sumica, Osaka, Japan).

For evaluating the retranslocation rate and determining the proportion of the foliar nutrients resorbed before leaf abscission, the nutrient resorption efficiency (NURE) from senescing leaves was calculated as follows (eqn. 1):

$$
N U R E=\left(C_{\text {live }}-C_{\text {senescing }}\right) / C_{\text {live }}
$$

where NURE is the nutrient resorption efficiency, $C_{\text {live }}$ is the nutrient concentration of live leaves and $C_{\text {senescing }}$ is the nutrient concentration of senescing leaves (Helmisaari 1992, Huang et al. 2007, Salehi et al. 2013). For each specific nutrient $X,(X)$ RE represents the resorption efficiency of nutrient $X$, where $X=\mathrm{N}, \mathrm{P}, \mathrm{Mg}, \mathrm{K}, \mathrm{Ca}, \mathrm{Mn}, \mathrm{Fe}$ and Al.

\section{Statistical analysis}

Parameter values for each species and each treatment were averaged over at least 3-4 replications, in order to provide the sample estimate for the actual replicate. Each NURE was subjected to linear mix model as follows (eqn. 2);

\section{$N U R E=G A S+$ Soil + GAS $\times$ Soil + Plot}

where $G A S$ is the treatment of ozone (ambient and $\mathrm{eO}_{3}$ ), Soil is the treatment of soil (B, S and V), GAS $\times$ Soil is the interac- 
Tab. 1 - Mean ( \pm standard deviation) nutrient resorption efficiency (NURE) of $\mathrm{Mg}, \mathrm{K}, \mathrm{Ca}, \mathrm{Mn}, \mathrm{Fe}$ and $\mathrm{Al}$ in birch seedlings grown on 3 soil types (B: brown forest soil; S: serpentine soil; V: volcanic ash soil) under 2 gas treatments $\left(\mathrm{A}\right.$ : ambient $\mathrm{O}_{3}$; E: elevated $\mathrm{O}_{3}$ ). Twoway analysis of variance (ANOVA) followed by Duncan's Multiple Range tests were used to compare the NURE differences among the 6 treatments ( 3 replicates each). Different letters within each row (nutrient) indicate significant differences among treatments $(\alpha=0.05)$. (ns): treatment effect not significant; $(*): p<0.05 ;(* *): p<0.01 ;(* * *): p<0.001$ (ANOVA).

\begin{tabular}{|c|c|c|c|c|c|c|c|c|c|}
\hline Birch & $A B$ & EB & AS & ES & AV & EV & Gas & Soil & Gas $\times$ Soil \\
\hline Mg & $-0.472 \pm 0.086^{a}$ & $-0.010 \pm 0.314^{a}$ & $-0.177 \pm 0.249^{a}$ & $-0.510 \pm 0.173^{a}$ & $-0.227 \pm 0.098^{a}$ & $-0.472 \pm 0.066^{a}$ & ns & ns & ns \\
\hline K & $0.261 \pm 0.009^{a}$ & $0.257 \pm 0.031^{\mathrm{a}}$ & $0.239 \pm 0.046^{a}$ & $0.242 \pm 0.015^{a}$ & $0.334 \pm 0.026^{a}$ & $0.157 \pm 0.084^{a}$ & ns & ns & ns \\
\hline $\mathrm{Ca}$ & $-0.624 \pm 0.160^{c d}$ & $-0.744 \pm 0.078^{d}$ & $-0.242 \pm 0.075^{a}$ & $-0.364 \pm 0.021 \mathrm{abc}$ & $-0.258 \pm 0.077^{a b}$ & $-0.541 \pm 0.064^{b c}$ & * & $* *$ & ns \\
\hline $\mathrm{Mn}$ & $-0.650 \pm 0.269^{a}$ & $-0.605 \pm 0.113^{a}$ & $-0.611 \pm 0.043^{a}$ & $-0.508 \pm 0.057^{\mathrm{a}}$ & $-0.328 \pm 0.049^{a}$ & $-1.050 \pm 0.065^{b}$ & ns & ns & * \\
\hline $\mathrm{Fe}$ & $-3.180 \pm 0.504^{b}$ & $-3.224 \pm 0.517^{b}$ & $-1.262 \pm 0.039^{a}$ & $-1.579 \pm 0.073^{a}$ & $-1.513 \pm 0.275^{a}$ & $-1.854 \pm 0.224^{a}$ & ns & $* * *$ & ns \\
\hline $\mathrm{Al}$ & $-4.575 \pm 0.371^{b}$ & $-2.503 \pm 0.268^{a}$ & $-2.250 \pm 0.312^{a}$ & $-2.649 \pm 0.139^{a}$ & $-2.597 \pm 0.363^{\mathrm{a}}$ & $-2.186 \pm 0.058^{a}$ & * & $* *$ & ** \\
\hline
\end{tabular}

tion of ozone and soil, and Plot is the location of each circular plot. We used $G A S$, Soil and GAS $\times$ Soil as fixed factors, and Plot as a random factor. The effects of each fixed factors were analyzed by likelihood ratio test, and we applied Tukey's post-hoc test when the likelihood ratio test was significant $(p<0.05)$. These analyses were performed separately on each species. These statistical analyses were performed using R (version 3.1.0 - http:// www.r-project.org/) with the "Imer" function of Ime4 package (Version 1.1-7 http://CRAN.R-project.org/p-ackage=Ime4). For the mineral elements $\mathrm{Mg}, \mathrm{K}, \mathrm{Ca}, \mathrm{Mn}$, $\mathrm{Fe}$ and $\mathrm{Al}$, two-way analysis of variance (ANOVA) was used to test the effects of $\mathrm{O}_{3}$ exposure and soil types as well as their interaction. Results were considered significant when $p<0.05$. Duncan's Multiple Range tests were utilized to compare the NURE differences among the 6 treatments. These statistical analyses were performed using the software package SPSS ${ }^{\circledast}$ ver. 21.0 (IBM, NY, USA).

\section{Results and discussion}

In general, foliar elements are transported through xylem and phloem, and their content results from the balance between influx via xylem and phloem, and efflux via phloem (Larcher 2003). Water soluble elements such as $\mathrm{N}, \mathrm{P}$ and $\mathrm{K}$ are known to be mobile in the phloem and readily retranslocated from older to younger leaves (Marschner 2012). Consequently, $\mathrm{N}, \mathrm{P}$ and $\mathrm{K}$ become unstable during leaf senescence, and are usually transported to other parts of the plant, resulting in a decrease of their concentration in senescing leaves (Helmisaari 1992).

On the other hand, the non-mobile mineral elements $\mathrm{Ca}, \mathrm{Mn}, \mathrm{Fe}$ and $\mathrm{Al}$ are transported from roots to leaves through xylem but are poorly mobile in phloem (Schulze et al. 2005, Marschner 2012, Shi et al. 2016). Therefore, content deficiencies of these elements commonly occur in younger leaves.

$\mathrm{Mg}$ is the central atom of chlorophyll pigment, and is essential for ribosome aggregation. In addition, it is often regarded as one of the indicators for leaf greenness and many physiological functions (Killingbeck 2004). Because of its mobility and availability in plants (Gjengedal 1996), Mg is usually considered to decrease with leaf senescence (Helmisaari 1992). Therefore, positive values for $\mathrm{N}, \mathrm{P}, \mathrm{K}$ and $\mathrm{Mg}$, along with negative values of NURE for $\mathrm{Ca}, \mathrm{Mn}$, Fe and Al may be the expected results.

\section{Birch seedlings}

Notwithstanding the above considerations, (Mg)RE in birch was unexpectedly negative under every treatment (Tab. 1). This result is in agreement with the study of Carr et al. (2003), who reported an increased $\mathrm{Mg}$ concentration in aged leaves. It is possible that the dynamics of $\mathrm{Mg}$ in live leaves was suppressed by the increased foliar K, as we detected a negative correlation between $\mathrm{Mg}$ and $\mathrm{K}$ (Kayama \& Koike 2015).

Previous research suggested that nutrient retranslocation in late successional
Birch (N) RE



species can increase at nutrient-poor sites (Koike 2004). In this study, similar results were obtained at ambient $\mathrm{O}_{3}$ for 5 elements (N, P, Ca, Fe, Al - Fig. 1, Tab. 1) and at $\mathrm{eO}_{3}$ condition for ( $\mathrm{Ca}$ ) RE and ( $\mathrm{Fe}$ ) RE (Tab. 1). However, the contrasting result observed for (N)RE at eO $\mathrm{e}_{3}$ (Fig. 1a) suggests that NURE may be independent of the gradient of the nutrients in the soil (Nelson et al. 1995). Alternatively, NURE is likely decreased at nutrient-poor sites by the interaction effects of $\mathrm{eO}_{3}$ and soil fertility, as (N)RE was found to be significant in interaction of $\mathrm{eO}_{3}$ and soils (Fig. 1a). In any case, NURE was likely to be limited by the availability of nutrient gradients, as NURE of $\mathrm{N}$, $\mathrm{Ca}$ and $\mathrm{Fe}$ at $\mathrm{eO} 3$ and NURE of $\mathrm{P}, \mathrm{Ca}, \mathrm{Fe}$ and $\mathrm{Al}$ at the ambient site did not show significant differences in both $\mathrm{V}$ and $\mathrm{S}$ soils (Fig. 1 and Tab. 1).
Fig. 1 - Box-plot of nutrient resorption efficiency (NURE) values of (a) Nitrogen [(N)RE] and (b) Phosphorus [(P)RE] in birch seedlings subjected to 6 treatments (3 replications each). Green boxes indicate elevated $\mathrm{O}_{3}$ treatments (EB, ES, EV), white boxes ambient $\mathrm{O}_{3}$ treatments $(A B, A S, A V)$. B, S, and $\mathrm{V}$ indicate different soil types (see Tab. 1). Effects of each fixed factors were tested by the likelihood ratio (LR) test, and Tukey's post-hoc test was used when LR test was significant. Different letters indicate significant pairwise differences between treatments $(\alpha=0.05)$. Box: interquartile range; whiskers: lower and upper quartiles; thick horizontal line within boxes: median; circles: extreme values. (ns): treatment effect not significant; $(*): p<0.05$; (**): $p<0.01$. 


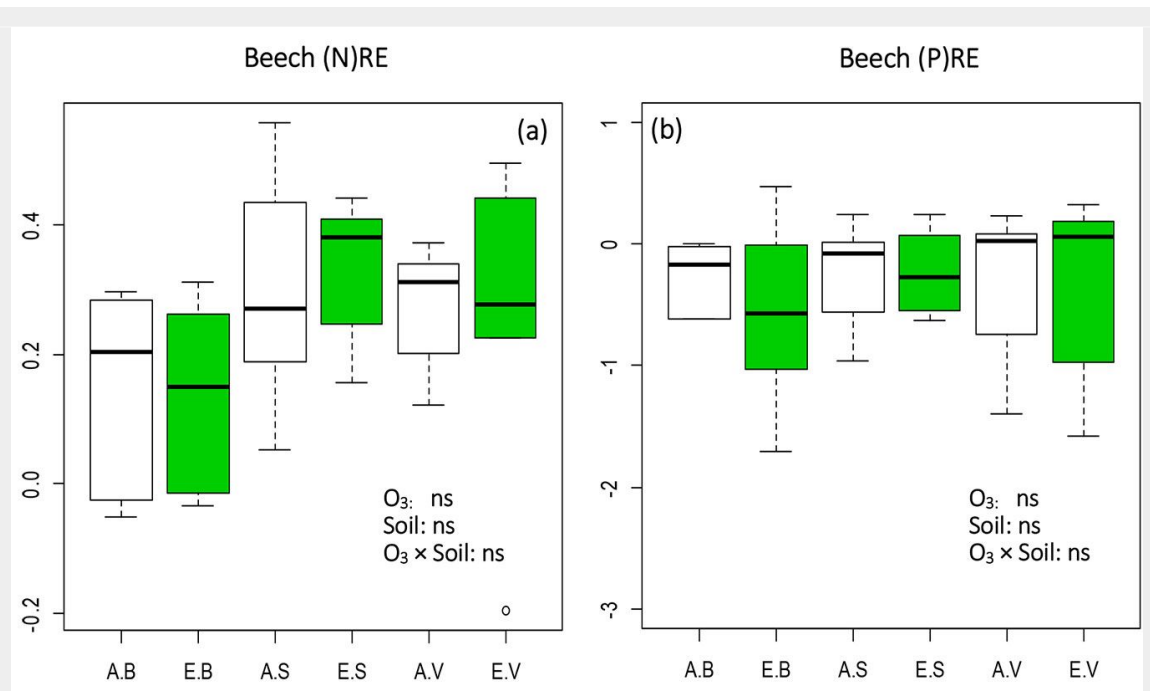

Fig. 2 - Box-plot of nutrient resorption efficiency (NURE) values of (a) Nitrogen $[(\mathrm{N}) \mathrm{RE}]$ and (b) Phosphorus [(P)RE] in beech seedlings subjected to 6 treatments (3 replications each). Green boxes indicate elevated $\mathrm{O}_{3}$ treatments (EB, ES, EV), white boxes ambient $\mathrm{O}_{3}$ treatments ( $\left.A B, A S, A V\right)$. B, S, and $V$ indicate different soil types (see Tab. 2). Effects of each fixed factors were tested by the likelihood ratio (LR) test, and Tukey's post-hoc test was used when LR test was significant. Different letters indicate significant pairwise differences between treatments $(\alpha=0.05)$. Box: interquartile range; whiskers: lower and upper quartiles; thick horizontal line within boxes: median; circles: extreme values. (ns): treatment effect not significant.

We expected that $\mathrm{O}_{3}$ would be detrimental to plant photosynthetic performances (Uddling et al. 2006, Koike et al. 2013) and nutrient dynamics, resulting in a lower NURE at $\mathrm{eO}_{3}$ due to the $\mathrm{O}_{3}$-induced reduction of translocation from older to younger leaves. As an example, the $(\mathrm{Mn}) \mathrm{RE}$ value of plants grown in the $V$ soil (Tab. 1) was significantly decreased by $\mathrm{eO}_{3}$. Such decrease may be attributed to the reduction of $\mathrm{Mn}$ in live leaves caused by the decline of photosynthetic functions and by the low Gs induced by $\mathrm{eO}_{3}$ (Yamaguchi et al. 2011, Shi et al. 2016). Contrastingly, NURE of N, P (Fig. 1a, Fig. 1b) and Al (Tab. 1) were markedly increased by $\mathrm{eO}_{3}$. According to Hoshika et al. (2013b), live leaves show a higher capacity of avoidance for $\mathrm{O}_{3}$-induced low Gs, thus being less susceptible to $\mathrm{O}_{3}$ stress than senescing leaves in birch (Hoshika et al. 2012, 2013b). Therefore, the decreased concentration of the above elements in senescing leaves at $\mathrm{eO}_{3}$ may be the result of their increased NURE.
Furthermore, Mn showed a significantly higher accumulation in senescing leaves of plants grown in $\mathrm{V}$ soil at $\mathrm{eO}_{3}$, as compared with other soils at $\mathrm{eO}_{3}$ (Tab. 1). According to the literature (Kitao et al. 1998), Mn tends to have a lower mobility when it is limiting to the plant, thus the deficiency of $\mathrm{Mn}$ in the $\mathrm{V}$ soil may explain its higher accumulation in the leaves of plants grown under $\mathrm{eO}_{3}$.

\section{Beech seedlings}

$(\mathrm{N}) \mathrm{RE}$ and $(\mathrm{P})$ RE were decreased under $\mathrm{eO}_{3}$ in beech, with the exception of $(\mathrm{N}) \mathrm{RE}$ in the AS and ES treatments. Since no significant effects of $\mathrm{O}_{3}$ and soil (or their interaction) on $\mathrm{N}$ and $\mathrm{P}$ were detected (Fig. 2), the observed NURE decrease was likely due to the leaching of $N$ and $P$ in senescing leaves under $\mathrm{eO}_{3}$ (Helmisaari \& Mälkönen 1989). In contrast, (N)RE in the ES treatment reached the highest value compared to other treatments (Fig. 2a), suggesting that more $\mathrm{N}$ was allocated to live leaves of beech for plant growth. This is especially important for plants grown in poor fertility soils like $\mathrm{S}$ soil in this study.

Yamaguchi et al. (2007) reported that the sensitivity of growth and photosynthetic parameters to $\mathrm{O}_{3}$ in beech became high at higher concentrations of $\mathrm{N}$ in the soil. Moreover, Hoshika et al. (2013b) concluded that late leaves in birch were more susceptible to $\mathrm{O}_{3}$ stress. In this context, the higher NURE values observed at $\mathrm{eO}_{3}$ in high fertility soils may be a consequence of the lower retention of elements in senescing leaves. Indeed, we found NURE values at $\mathrm{eO}_{3}$ markedly higher in the $\mathrm{B}$ soil than in other soils for K, Ca, Mn and Al (Tab. 2).

In addition, Fe and AI NURE were significantly enhanced by $\mathrm{eO}_{3}$ treatments in both $\mathrm{V}$ and $\mathrm{S}$ soils and in $\mathrm{V}$ soil alone, respectively (Tab. 2). Fe and Al were indicative of the reduced accumulation of elements in senescing leaves at specific treatments. It has recently been shown that $\mathrm{N}$ deficiencyinduced leaf senescence (as in the case of $V$ and $S$ soil types) enhances Fe mobilization in old leaves, thereby leading to the decline of foliar Fe accumulation (Barunawati et al. 2013, Shi et al. 2012). Regarding the higher $\mathrm{Al}(\mathrm{RE})$ observed under $\mathrm{eO}_{3}$ in beech, the possible explanation is similar to that discussed above for birch. However, the $\mathrm{O}_{3}$-induced reduction of $\mathrm{Al}$ concentration in older leaves of beech (Hoshika et al. 2013b, Yamaguchi et al. 2007) may not be adequately counterbalanced by the increase in foliar Al during leaf senescence in plants growing on acidic soils (Gjengedal 1996), and this may explain the increase of (Al)RE in the treatment EV observed in this study (Tab. 2).

On the other hand, a decrease in (Mg)RE in $B$ and $S$ soils, NURE of $K$ and $C a$ in $S$ and $\mathrm{V}$ soils, $(\mathrm{Mn}) \mathrm{RE}$ in $\mathrm{B}$ and $\mathrm{V}$ soils were observed in plants grown under $\mathrm{eO}_{3}$ (Tab. 2). Beside the aforementioned $\mathrm{O}_{3}$-induced reduction of translocation, the concentration of those nutrients in live leaves could be affected by leaching (Helmisaari 1992, Gjengedal 1996, Vergutz et al. 2012). Previous research demonstrated that foliar leaching of $\mathrm{Ca}, \mathrm{K}$ and $\mathrm{Mg}$ can be observed on acidified soil and is believed to occur via cation exchange (Gjengedal 1996). These results may suggest that foliar leaching is independent from soil acidification, at least in

Tab. 2 - Mean ( \pm standard deviation) nutrient resorption efficiency (NURE) of $\mathrm{Mg}, \mathrm{K}, \mathrm{Ca}, \mathrm{Mn}, \mathrm{Fe}$ and $\mathrm{Al}$ in beech seedlings grown on 3 soil types (B: brown forest soil; S: serpentine soil; V: volcanic ash soil) under 2 gas treatments (A: ambient $\mathrm{O}_{3}$; E: elevated $\mathrm{O}_{3}$ ). Twoway analysis of variance (ANOVA) followed by Duncan's Multiple Range tests were used to compare the NURE differences among the 6 treatments ( 3 replicates each). Different letters within each row (nutrient) indicate significant differences among treatments $(\alpha=0.05)$. (ns): treatment effect not significant ; $\left(^{*}\right): p<0.05 ;(* *): p<0.01 ;(* * *): p<0.001$ (ANOVA).

\begin{tabular}{|c|c|c|c|c|c|c|c|c|c|}
\hline Beech & $A B$ & EB & AS & ES & AV & EV & Gas & Soil & Gas $\times$ Soi \\
\hline $\mathrm{Mg}$ & $-0.020 \pm 0.174^{a b}$ & $-0.849 \pm 0.863^{c}$ & $0.436 \pm 0.006^{a}$ & $-0.449 \pm 0.207^{b c}$ & $0.202 \pm 0.055^{\mathrm{ab}}$ & $-0.135 \pm 0.049 a b c$ & ** & ns & ns \\
\hline $\mathrm{K}$ & $0.216 \pm 0.053^{a}$ & $0.238 \pm 0.083^{a}$ & $0.310 \pm 0.069^{a}$ & $-0.063 \pm 0.070^{b}$ & $0.144 \pm 0.017^{a}$ & $-0.020 \pm 0.012^{b}$ & $* *$ & $*$ & $* *$ \\
\hline $\mathrm{Ca}$ & $0.043 \pm 0.028^{a}$ & $-0.093 \pm 0.041$ ab & $-0.099 \pm 0.073 a b$ & $-0.345 \pm 0.085^{c}$ & $0.068 \pm 0.021^{a}$ & $-0.150 \pm 0.049^{b}$ & $* *$ & ** & ns \\
\hline $\mathrm{Mn}$ & $0.487 \pm 0.035^{\mathrm{a}}$ & $-0.039 \pm 0.043^{b}$ & $-0.630 \pm 0.066^{c}$ & $-0.352 \pm 0.097^{c}$ & $0.135 \pm 0.072^{b}$ & $-0.455 \pm 0.171^{c}$ & ** & $* * *$ & ** \\
\hline $\mathrm{Fe}$ & $-0.148 \pm 0.017^{a}$ & $0.095 \pm 0.125^{a}$ & $-1.082 \pm 0.343^{b}$ & $0.005 \pm 0.058^{a}$ & $-1.420 \pm 0.246^{b}$ & $-0.416 \pm 0.105^{a}$ & $* * *$ & ** & ns \\
\hline $\mathrm{Al}$ & $-0.276 \pm 0.058$ ab & $0.013 \pm 0.030^{a}$ & $-0.561 \pm 0.179^{b}$ & $-0.353 \pm 0.053^{b}$ & $-1.265 \pm 0.239^{c}$ & $-0.467 \pm 0.088^{b}$ & $* * *$ & $* * *$ & * \\
\hline
\end{tabular}


beech. Moreover, the Al toxicity may also cause the inhibition of some mineral nutrients resorption during senescence (Schulze et al. 2005).

\section{Oak seedlings}

No significant effects of $\mathrm{O}_{3}$ on the NURE of $\mathrm{N}$ and $\mathrm{P}$ were detected in oak seedlings, though an increase of (N)RE and (P)RE in plants grown in both $\mathrm{S}$ and $\mathrm{V}$ soils under elevated $\mathrm{O}_{3}$ was observed (Fig. 3). Also, $(\mathrm{N}) \mathrm{RE}$ and $(\mathrm{P}) \mathrm{RE}$ were clearly higher in leaves from plants grown in the $V$ soil than in the S soil. Helmisaari (1992) emphasized that foliar NURE does not vary in response to soil fertilization. Therefore, we hypothesized that higher $(\mathrm{N}) \mathrm{RE}$ and $(\mathrm{P}) \mathrm{RE}$ in $\mathrm{V}$ soil may reflect soil depletion and acidification. Indeed, depletion-driven losses of $\mathrm{N}$ and $\mathrm{P}$ in the soil are associated with a decreased retention of $N$ and $P$ in senescent leaves and strongly increased NUREs (Hayes et al. 2014). Accordingly, the higher NURE of $N$ and $\mathrm{P}$ in $\mathrm{V}$ soil (Fig. 3) may result from the high depletion-driven loss in V (acidic) soil, as output $\mathrm{N}$ had a high negative correlation with soil pH (Dise \& Wright 1995).

Similarly, the markedly higher (Ca)RE observed in the $\mathrm{V}$ soil compared to the $\mathrm{S}$ soil in the ambient $\mathrm{O}_{3}$ treatments (Tab. 3) suggests that higher depletion-driven loss in $\mathrm{V}$ soil may also affect $\mathrm{Ca}$. In contrast, significantly lower ( $\mathrm{Ca}$ )RE in $\mathrm{V}$ than in $\mathrm{S}$ soil was observed in treatments under $\mathrm{eO}_{3}$, likely due to soil type- $\mathrm{O}_{3}$ interactions. In particular, the enhanced NURE caused by soil was not adequately compensated by $\mathrm{O}_{3}$-induced detrimental effects on NURE. Such combined influences may largely affect other elements in oak plants.

(AI)RE in high fertility soil (B soil) was the highest in controls (ambient $\mathrm{O}_{3}$ ) but clearly the lowest under $\mathrm{eO}_{3}$ (Tab. 3). Retranslocated nutrients are generally essential for the production of new tissues and organs throughout all stages of plant development. This suggests that soil and environmental factors that facilitate plant growth also promote nutrient retranslocation and vice versa (Nambiar \& Fife 1991). As a result, NURE is expected to increase in highfertility soils but to decrease under $\mathrm{eO}_{3}$. Therefore, the markedly highest $(\mathrm{Mn}) \mathrm{RE}$ and (Al)RE in $A B$ (Tab. 3) may be the result of the relatively high-fertility soil conditions
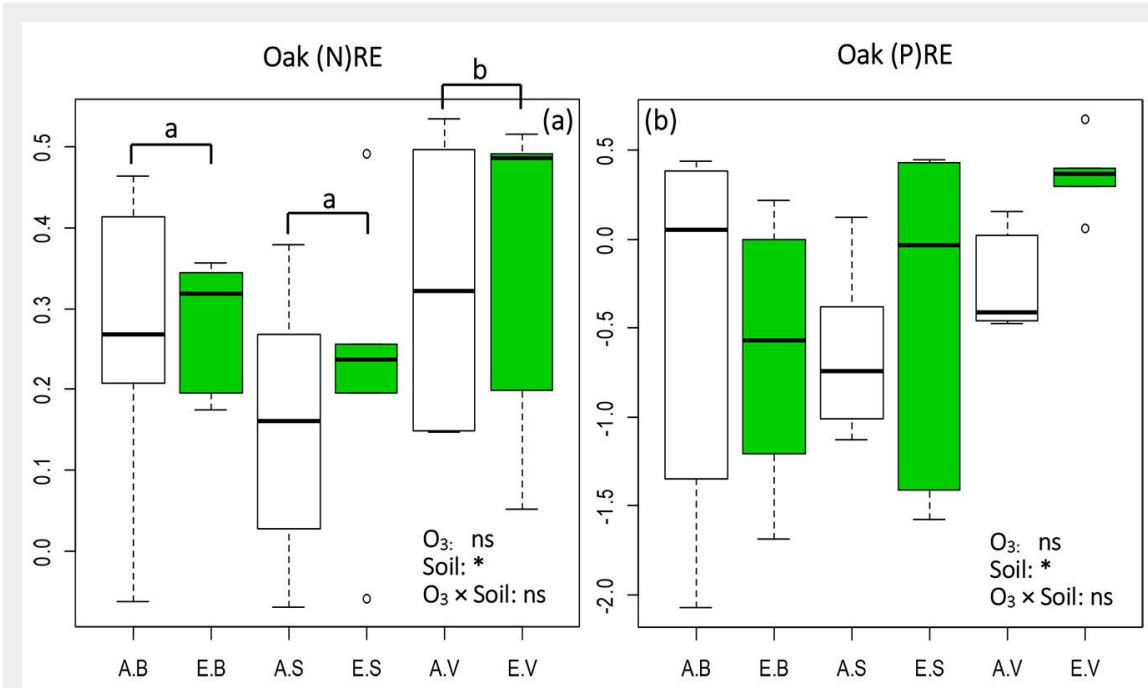

Fig. 3 - Box-plot of nutrient resorption efficiency (NURE) values of (a) Nitrogen [(N)RE] and (b) Phosphorus [(P)RE] in oak seedlings subjected to 6 treatments (3 replications each). Green boxes indicate elevated $\mathrm{O}_{3}$ treatments (EB, ES, EV), white boxes ambient $\mathrm{O}_{3}$ treatments $(A B, A S, A V)$. B, S, and $V$ indicate different soil types (see Tab. 3). Effects of each fixed factors were tested by the likelihood ratio (LR) test, and Tukey's post-hoc test was used when LR test was significant. Different letters indicate significant pairwise differences between treatments $(\alpha=0.05)$. Box: interquartile range; whiskers: lower and upper quartiles; thick horizontal line within boxes: median; circles: extreme values. (ns): treatment effect not significant; $(*)$ : $p<0.05$.

(B soil) where plants were grown, whereas the significant low (Fe)RE and (Al)RE in EB (Tab. 3) may be due to the effect of interactions between $\mathrm{O}_{3}$ and soil. Nevertheless, the declined NURE caused by $\mathrm{eO}_{3}$ may be aggravated by the relative high $\mathrm{N}$ in soil and finally results in the low NURE values (Yamaguchi et al. 2007).

\section{Comparisons among birch, beech and oak seedlings}

Considering the overall impacts of the $\mathrm{eO}_{3}$ exposure on the foliar mineral nutrients investigated ( $\mathrm{Mg}, \mathrm{K}, \mathrm{Ca}, \mathrm{Mn}$, Fe and Al), beech was the most affected (Tab. 2), followed by oak (Tab. 3) and birch (Tab. 1). This was inconsistent with previous studies reporting birch as the most and beech as the least sensitive species to $\mathrm{eO}_{3}$ (Yamaguchi et al. 2011). These contrasting results may be attributable to differences in patterns of leaf development and growth among species (Hoshika et al. 2013a, Kiku- zawa \& Lechowicz 2011). Indeed, birch shows an indeterminate growth pattern (Koike 1995, Hoshika et al. 2013b), while beech and oak typically have determinate (Kitao et al. 2009) and semi-determinate patterns (Holbrook \& Zwieniecki 2011), respectively. However, it is worth noting that such classification of shoot growth patterns is not clear-cut and considerable overlaps do exists in between classes. In any case, indeterminate growth patterns may promote the production of new leaves to compensate the damage caused by $\mathrm{eO}_{3}$ (Hoshika et al. 2013a, 2013b), and this may explain why birch is the least affected species in terms of effects of $\mathrm{eO}_{3}$ on mineral nutrients, as compared with beech and oak (Tab. 1).

In addition, beech seedlings were the most affected by soil type concerning the mineral nutrients investigated (Tab. 2), whereas oak was the most tolerant species in terms of impact of soil conditions on

Tab. 3 - Mean ( \pm standard deviation) nutrient resorption efficiency (NURE) of $\mathrm{Mg}, \mathrm{K}, \mathrm{Ca}, \mathrm{Mn}$, Fe and $\mathrm{Al}$ in oak seedlings grown on 3 soil types (B: brown forest soil; S: serpentine soil; V: volcanic ash soil) under 2 gas treatments (A: ambient $\mathrm{O}_{3}$; E: elevated $\mathrm{O}_{3}$ ). Twoway analysis of variance (ANOVA) followed by Duncan's Multiple Range tests were used to compare the NURE differences among the 6 treatments ( 3 replicates each). Different letters within each row (nutrient) indicate significant differences among treatments $(\alpha=0.05)$. (ns): treatment effect not significant $\left(^{*}\right): p<0.05 ;(* *): p<0.01 ;(* * *): p<0.001$ (ANOVA).

\begin{tabular}{|c|c|c|c|c|c|c|c|c|c|}
\hline Oak & $A B$ & EB & AS & ES & AV & EV & Gas & Soil & Gas $\times$ Soil \\
\hline$M g$ & $-0.166 \pm 0.046^{a}$ & $0.269 \pm 0.222^{a}$ & $-0.317 \pm 0.252^{a}$ & $0.075 \pm 0.058^{a}$ & $0.172 \pm 0.122^{a}$ & $-0.167 \pm 0.179^{a}$ & ns & ns & ns \\
\hline $\mathrm{K}$ & $-0.189 \pm 0.022^{a}$ & $-0.007 \pm 0.062^{a}$ & $0.068 \pm 0.051^{a}$ & $0.053 \pm 0.183^{a}$ & $0.073 \pm 0.062^{\mathrm{a}}$ & $-0.308 \pm 0.230^{\mathrm{a}}$ & ns & ns & ns \\
\hline $\mathrm{Ca}$ & $-0.055 \pm 0.064^{b c}$ & $-0.109 \pm 0.026^{b c}$ & $-0.280 \pm 0.020^{d}$ & $0.148 \pm 0.160^{a}$ & $0.049 \pm 0.033^{\mathrm{ab}}$ & $-0.157 \pm 0.021^{c d}$ & ns & ns & *** \\
\hline $\mathrm{Mn}$ & $-0.753 \pm 0.330^{b}$ & $-0.444 \pm 0.203^{a b}$ & $-1.759 \pm 0.444^{c}$ & $0.100 \pm 0.010^{a}$ & $-2.121 \pm 0.033^{c}$ & $0.255 \pm 0.034^{\mathrm{a}}$ & *** & ns & ** \\
\hline $\mathrm{Fe}$ & $-0.208 \pm 0.059^{a}$ & $-1.730 \pm 0.490^{b}$ & $-0.722 \pm 0.181^{a}$ & $-0.312 \pm 0.343^{a}$ & $-0.327 \pm 0.040^{a}$ & $-0.085 \pm 0.048^{a}$ & ** & * & ** \\
\hline $\mathrm{Al}$ & $-0.241 \pm 0.092^{a}$ & $-1.481 \pm 0.085^{d}$ & $-0.593 \pm 0.037^{b}$ & $-0.164 \pm 0.090^{a}$ & $-0.984 \pm 0.069^{c}$ & $-0.513 \pm 0.115^{b}$ & ns & $* * *$ & $* * *$ \\
\hline
\end{tabular}


nutrient retranslocation (Tab. 3). Although beech is a typical late-successional tree species (Koike 2004, Kitao et al. 2009), it often retranslocates more foliar nutrients before leaf shedding when growing on infertile soils, compared to early or midsuccessional species such as birch and oak (Killingbeck 2004, Koike 2004, Eguchi et al. 2008). The results obtained in this study further support such evidence.

\section{Conclusion}

In summary, NURE is deeply affected by $\mathrm{eO}_{3}$ and soil types in saplings of 3 Japanese representative tree species and considerable differences in nutrient acquisition and loss in leaves were found among species (Koike 2004, Hayes et al. 2014). The effect of ozone and soil varied across species with different growth patterns. The retranslocation of mineral nutrients was more efficient in beech, which has a determinate shoot growth pattern and showed a relatively high sensitivity of foliar NURE to either $\mathrm{eO}_{3}$ or nutrient content in the soil. Based on our results, foliar NURE may be considered a good indicator of the physiological conditions of plants to be monitored in field surveys. Studies on the retranslocation of foliar nutrients may help develop appropriate strategies of nutrient management in plantations (Salehi et al. 2013).

\section{Acknowledgements}

We specially thank Dr. E. Paoletti for her valuable suggestions to this study and JSPS basic research (Type B: 26292075) to TK. Many thanks also to Dr. Y. Matsuura for references and to Mr. E. Agathokleous and Mr. D.-G. Kam for their kind help. We finally acknowledge Ms. S. Fujita for amendments to the manuscript language.

\section{References}

Adams MB, Peterjohn WT, Gilliam FS (2006). Acidification and nutrient cycling. In: "Chapter 7. The Fernow Watershed Acidification Study". Springer, the Netherlands, pp. 207-236. - doi: 10.1007/978-1-4020-4615-5_7

Barunawati N, Hettwer Giehl RF, Bauer B, Von Wirén N (2013). The influence of inorganic nitrogen fertilizer forms on micronutrient retranslocation and accumulation in grains of winter wheat. Frontiers in Plant Science 4: 1-11. doi: $10.3389 /$ fpls.2013.00320

Brady K, Kruckberg A, Bradshaw H (2005). Evolutionary ecology of plant adaptation to serpentine soils. Annual Review of Ecology, Evolution and Systematics 36: 243-266. - doi: 10.1146/annu rev.ecolsys.35.021103.105730

Carr HP, Lombi E, Küpper H, McGrath SP, Wong $\mathrm{MH}$ (2003). Accumulation and distribution of aluminum and other elements in tea (Camellia sinensis) leaves. Agronomie 23: 705-710. - doi: 10.1051/agro:2003045

Dise NB, Wright RF (1995). Nitrogen leaching from European forests in relation to nitrogen deposition. Forest Ecology and Management 71: 153-161. - doi: 10.1016/0378-1127(94)06092-W Eguchi N, Karatsu K, Ueda T, Funada R, Takagi K,
Hiura T, Sasa K, Koike T (2008). Photosynthetic responses of birch and alder saplings grown in a free air $\mathrm{CO}_{2}$ enrichment system in northern Japan. Trees 22: 437-447. - doi: 10.1007/s00468007-0204-5

Farahat E, Linderholm HW (2015). Nutrient resorption efficiency and proficiency in economic wood trees irrigated by treated wastewater in desert planted forests. Agricultural Water Management 155: 67-75. - doi: 10.1016/j.agwat.2015. 03.008

Gjengedal E (1996). Effects of soil acidification on foliar leaching and retranslocation of metals in vascular plants. Water, Air and Soil Pollution 86: 221-234. - doi: 10.1007/BF00279158

Hagen-Thorn A, Armolaitis KS, Callesen I, Stjernquist I (2004). Macronutrients in tree stems and foliage: a comparative study of six temperate forest species planted at the same sites. Annals of Forest Science 61: 489-498. - doi: 10.1051/forest:2004043

Hayes P, Turner BL, Lambers H, Laliberté E (2014). Foliar nutrient concentrations and resorption efficiency in plants of contrasting nutrient-acquisition strategies along a 2-millionyear dune chronosequence. Journal of Ecology 102: 396-410. - doi: 10.1111/1365-2745.12196

Helmisaari H, Mälkönen E (1989). Acidity and nutrient content of throughfall and soil leachate in three Pinus sylvestris stands. Scandinavian Journal of Forest Research 4: 13-18. - doi: 10.1080/02827588909382542

Helmisaari H (1992). Nutrient retranslocation within the foliage of Pinus sylvestris. Tree Physiology 10: 45-58. - doi: 10.1093/treephys/10.1.45 Holbrook NM, Zwieniecki MA (2011). Vascular transport in plants. Elsevier Academic Press, Burlington, USA, pp. 216. [online] URL: http:// books.google.com/books?id=nAW5uli_tQgC

Hoshika Y, Watanabe M, Inada N, Koike T (2012). Ozone-induced stomatal sluggishness develops progressively in Siebold's beech (Fagus crenata). Environmental Pollution 166: 152-156. - doi: 10.1016/j.envpol.2012.03.013

Hoshika Y, Pecori F, Conese I, Bardelli T, Marchi E, Manning WJ, Badea O, Paoletti E (2013a). Effect of a three-year exposure to ambient ozone on biomass allocation in poplar using ethylenediurea. Environmental Pollution 180: 299-303. - doi: 10.1016/j.envpol.2013.05.041

Hoshika Y, Watanabe M, Inada N, Mao Q, Koike T (2013b). Photosynthetic response of early and late leaves of white birch (Betula platyphylla var. japonica) grown under free-air ozone exposure. Environmental Pollution 182: 242-247. doi: 10.1016/j.envpol.2013.07.033

Huang J, Wang X, Yan E (2007). Leaf nutrient concentration, nutrient resorption and litter decomposition in an evergreen broad-leaved forest in eastern China. Forest Ecology and Management 239: 150-158. - doi: 10.1016/j.for eco.2006.11.019

Kam DG, Shi C, Watanabe M, Kita K, Satoh F, Koike T (2015). Growth of Japanese and hybrid larch seedlings grown under free-air $\mathrm{O}_{3}$ enrichment - an initial assessment of the effects of adequate and excessive nitrogen. Journal of Agricultural Meteorology 71: 239-244. - doi: 10.2480/agrmet.D-14-00029

Karnosky DF, Skelly JM, Percy KE, Chappelka AH (2007). Perspectives regarding 50 years of research on effects of tropospheric ozone air pollution on US forests. Environmental Pollution 147: 489-506. - doi: 10.1016/j.envpol.2006. 08.043

Kayama M, Satoh F, Koike T (2011). Photosynthetic rate, needle longevity, and nutrient contents in Picea glehnii growing on strongly acidic volcanic ash soil in northern Japan. Photosynthetica 49: 239-245. - doi: 10.1007/s11099-011-00 30-2

Kayama M, Koike T (2015). Differences in growth characteristics and dynamics of elements in seedlings of two birch species grown in serpentine soil in northern Japan. Trees-structure and function 29: 171-184. - doi: 10.1007/s00468-0141102-2

Kikuzawa K, Lechowicz MJ (2011). Ecology of leaf longevity. Springer, Tokyo, pp. 147. [online] URL: http://books.google.com/books?id=SX2ep fcaunwC

Killingbeck KT (2004). Nutrient resorption. In: "Plant Cell Death Processes" (Nooden LD ed). Elsevier, New York, USA, pp. 215-226.

Kim YS, Watanabe M, Imori M, Sasa K, Takagi K, Hatano R, Koike T (2011). Reduced atmospheric $\mathrm{CH}_{4}$ consumption by two forest soils under elevated $\mathrm{CO}_{2}$ concentration in a FACE system in northern Japan. Journal of Japanese Society of Atmospheric Environment 46: 30-36. [online] URL: http://www.jstage.jst.go.jp/article/taiki/46 /1/46_1_30/_article

Kitao M, Lei TT, Koike T (1998). Application of chlorophyll fluorescence to evaluate $\mathrm{Mn}$ tolerance of deciduous broad-leaved tree seedlings native to northern Japan. Tree Physiology 18: 135-140. - doi: 10.1093/treephys/18.2.135

Kitao M, Löw M, Heerdt C, Grams TEE, Häberle $\mathrm{KH}$, Matyssek R (2009). Effects of chronic elevated ozone exposure on gas exchange responses of adult beech trees (Fagus sylvatica) as related to the within-canopy light gradient. Environmental Pollution 157: 537-544. - doi: 10.1016/j.envpol.2008.09.016

Koike T (1995). Physiological ecology of the growth characteristics of Japanese mountain birch in northern Japan: a comparison with Japanese mountain white birch, In: "Vegetation Science in Forestry: Global Perspective based on Forest Ecosystems of East and Southeast Asia" (Box EO et al. eds). Kluwer, Dordrecht, Netherlands, pp. 409-422.

Koike T (2004). Autumn coloration, carbon acquisition and leaf senescence. In: "Plant Cell Death Processes" (Noodén LD ed). Elsevier, New York, USA, pp. 245-258.

Koike T, Kato S, Shimamoto Y, Kitamura K, Kawano S, Ueda K, Mikami T (1998). Mitochondrial DNA variation follows a geographic pattern in Japanese beech species. Botanica Acta 11: 87-91. - doi: 10.1111/j.1438-8677.1998.tboo68 2.x

Koike T, Watanabe M, Hoshika Y, Kitao M, Matsumura H, Funada R, Izuta T (2013). Chapter 17 Effects of ozone on forest ecosystems in East and Southeast Asia. Elsevier Developments in Environmental Science 13: 371-390. - doi: 10.1016 /B978-0-08-098349-3.00017-7

Larcher W (2003). Plant physiological ecology $\left(4^{\text {th }}\right.$ edn). Springer Verlag, Heidelberg, Germany, pp. 513.

Marschner P (2012). Marschner's mineral nutri- 
tion of higher plants ( $3^{\text {rd }}$ edn). Academic Press, London, UK, pp. 135-189.

Nambiar EKS, Fife DN (1991). Nutrient retranslocation in temperate conifers. Tree Physiology 9: 185-207. - doi: 10.1093/treephys/9.1-2.185

Nelson LE, Shelton MG, Switzer GL (1995). The influence of nitrogen application on resorption of foliar nutrients in sweetgum. Canadian Journal of Forest Research 25: 298-306. - doi: 10.1139/×95-034

Ohara T, Akimoto H, Kurokawa J, Horii N, Yamaji K, Yan X, Hayasaka T (2007). An Asian emission inventory of anthropogenic emission sources for the period 1980-2020. Atmospheric Chemistry and Physics Discussion 7: 6843-6902. - doi: 10.5194/acpd-7-6843-2007

Salehi A, Ghorbanzadeh N, Salehi M (2013). Soil nutrient status, nutrient return and retranslocation in poplar species and clones in northern Iran. iForest -Biogeoscience and Forestry 6: 336-341. - doi: 10.3832/iforo976-006

Salifu KF, Timmer VR (2001). Nutrient retranslocation response of Picea mariana seedlings to nitrogen supply. Soil Science Society of American Journal 65: 905-913. - doi: 10.2136/sssaj20 $01.653905 x$

Schulze E-D, Erwin B, Klaus MH (2005). Plant ecology. Springer, Berlin, Germany, pp. 195206.

Serengil $Y$, Augustaitis A, Bytnerowicz A, Grulke N, Kozovitz AR, Matyssek R, Müller-Starck $G$, Schaub M, Wieser G, Coskun AA, Paoletti E (2011). Adaptation of forest ecosystems to air pollution and climate change: a global assessment on research priorities. iForest - Biogeo- science and Forestry 4: 44-48. - doi: 10.3832/ ifor0566-004

Shi C, Kitao M, Agathokleous E, Watanabe M, Tobita H, Yazaki K, Kitaoka S, Koike T (2016). Chemical composition of two oak seedlings grown under elevated $\mathrm{O}_{3}$ and $\mathrm{CO}_{2}$ with a freeair enrichment system. Journal of Agriculture Meteorology 72: 50-58. - doi: 10.2480/agrmet.D14-00018

Shi RL, Weber G, Koster J, Reza-Hajirezaei M, Zou C, Zhang F, Von Wirén N (2012). Senescence-induced iron mobilization in source leaves of barley (Hordeum vulgare) plants. New Phytologist 195: 372-383. - doi: 10.1111/j.14698137.2012.04165.X

Uddling J, Karlsson PE, Glorvigen A, Sellden G (2006). Ozone impairs autumnal resorption on nitrogen from birch (Betula pendula) leaves, causing an increase in whole-tree nitrogen loss through litter fall. Tree Physiology 26: 113-120. doi: 10.1093/treephys/26.1.113

Vergutz L, Manzoni S, Porporato A, Novais RF, Jackson RB (2012). Global resorption efficiencies and concentrations of carbon and nutrients in leaves of terrestrial plants. Ecological Monographs 82: 205-220. - doi: 10.1890/11-041 6.1

Watanabe M, Yamaura S, Takamatsu T, Koshikawa MK, Hayashi S, Murata T, Saito SS, Inubushi K, Sakamoto K (2010). Microbial biomass and nitrogen transformations in surface soils strongly acidified by volcanic hydrogen sulfide deposition in Osorezan, Japan. Soil Science and Plant Nutrition 56: 123-132. - doi: 10.1111/j.17470765.2009.00438.x
Watanabe M, Ryu K, Kita K, Takagi K, Koike T (2012). Effect of nitrogen load on growth and photosynthesis of seedlings of the hybrid larch F1 (Larix gmelinii var. japonica $\times$ L. kaempferi) grown on serpentine soil. Environmental and Experimental Botany 83: 73-81. - doi: 10.1016/j. envexpbot.2012.04.011

Watanabe M, Hoshika Y, Inada N, Wang X, Mao Q, Koike T (2013). Photosynthetic traits of Siebold's beech and oak saplings grown under free air ozone exposure in northern Japan. Environmental Pollution 174: 50-56. - doi: 10.1016/ j.envpol.2012.11.006

Xu XJ, Timmer VR (1999). Growth and nitrogen nutrition of Chinese fir seedlings exposed to nutrient loading and fertilization. Plant and Soil 216: 83-91. - doi: 10.1023/A:1004733714217

Yamaguchi M, Watanabe M, Matsuo N, Naba J, Funada R, Fukami M, Matsumura $\mathrm{H}$, Kohno $\mathrm{Y}$, Izuta $T$ (2007). Effects of nitrogen supply on the sensitivity to $\mathrm{O}_{3}$ of growth and photosynthesis of Japanese beech (Fagus crenata) seedlings. Water, Air and Soil Pollution 7: 131-136. doi: 10.1007/s11267-006-9094-6

Yamaguchi $M$, Watanabe $M$, Matsumura $H$, Kohno Y, Izuta T (2011). Experimental studies on the effects of ozone on growth and photosynthetic activity of Japanese forest tree species. Asian Journal of Atmospheric Environment 5: 65-78. - doi: 10.5572/ajae.2011.5.2.065

Zhao B, Ren P, Liu J, Zhao M (2013). Nitrogen accumulation, retranslocation and partitioning in oats (Avena L.) as affected by different water supply and nitrogen fertilization. Advanced Materials Research 610-613: 2963-2967. 